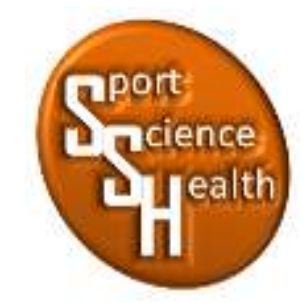

ISSN 2715-3886

\title{
Pengembangan Media Pembelajaran Berbasis Mobile Learning Untuk Aktifitas Kesegaran Jasmani Siswa kelas X Sekolah Menengah Kejuruhan
}

\author{
Ibnu Aji Pamungkas Universitas Negeri Malang \\ Wasis Djoko Dwijoyo : Universitas Negeri Malang \\ ibnuaji_pamungkas@yahoo.co.id
}

081247513422

\begin{abstract}
Abstrak
Penelitian ini bertujuan untuk mengembangkan media pembelajaran berbasis mobile learning untuk aktifitas kesegaran jasmani. Metode yang digunakan dalam penelitian dan pengembangan ini menggunakan pendekatan Research and Development. Subjek yang digunakan adalah siswa siswi kelas $\mathrm{X}$ Jurusan Perhotelan 3 SMK Negeri 1 Batu. Instrumen pengumpulan data berupa observasi, dan kuesioner. Teknik analisis data dalam penelitian ini berupa deskriptif persentase yang digunakan untuk mengolah data kualitatif dan kuantitatif. Penelitian ini telah melalui 2 validasi ahli, yaitu 1 ahli kebugaran jasmani dan 1 ahli media dengan hasil diperoleh rata-rata persentase ahli pembelajaran kebugaran jasmani sebesar $100 \%$, ahli media $96 \%$, dan uji coba kelompok sebesar $90 \%$. Sehingga produk dinyatakan layak dan valid untuk digunakan. Selanjutnya dilakukan uji efektiftas produk yang memiliki nilai 83\%, uji efisiensi dengan catatan waktu 29 menit, dan uji kemenarikan produk dengan hasil presentase $83 \%$. Jadi Kesimpulannya bahwa pembelajaran kebugaran jasmani berbasis mobile learning yang didukung dengan hasil tersebut maka produk yang dikembangkan masuk data kriteria amat baik sehingga produk pengembangan media pembelajaran berbasis mobile learning untuk aktifitas kesegaran jasmani pada siswa SMKN 1 Batu dapat digunakan pada proses pembelajaran dan latihan.
\end{abstract}

\section{Kata kunci}

media Pembelajaran, Mobile Learning, Kebugaran Jasmani

\section{PENDAHULUAN}

Perkembangan teknologi yang begitu pesat membuat masyarakat dimanjakan dengan segala inovasinya. Padahal tanpa disadari perkembangan teknologi tersebut memilik berbagai dampak, baik dampak positif maupun dampak negative. Pada satu sisi masyarakat memang mengalami berbagai kemudahan dalam segala hal, namun di sisi lain tanpa sadar masyarakat menjadi malas untuk melakukan aktifitas fisik di kehidupan sehari-hari. Bahkan dengan adanya perkembangan teknologi kini masyarakat hampir tidak perlu 
mengeluarkan energi yang terlalu besar untuk mencapai tempat kerjanya, mencuci, memasak, ataupun menyelesaikan tuntutan pekerjaannya. Segala sesuatu sudah ada mesin yang bahkan sudah dilengkapi dengan sistem digital yang menjadikan segala sesuatunya bekerja secara otomatis, cepat dan efisien. Perkembangan teknologi ternyata tidak hanya merambah pada dunia kerja dan dunia orang dewasa, namun juga merambah pada dunia anak.

Era milenial membuat anak menjadi malas bergerak dan terfokus pada teknologi yang ia miliki. Padahal, perkembangan kognitf dan psikomotor anak sangatlah berbahaya apabila tidak adanya stimulus untuk mengembangkanya (Adi \& Fathoni, 2019). Untuk itu, Olahraga berperan penting dalam tumbuh kembang anak, baik secara fisik maupun mental, dari aktivitas bermain yang membentuk keterampilan motorik dan neuromuskular. Anak dapat menguasai dasar keterampilan lokomotor, non-lokomotor serta keterampilan manipulasi. Anak usia dini dapat diperkenalkan berbagai hal tentang benda dan orang-orang disekitarnya melalui aktivitas olahraga. Pengenalan berbagai pola, sikap dan perilaku, kebiasaan dan sifat benda serta orang-orang yang ada disekitarnya akan membantu anak memahami aspek-aspek psikologi dari lingkungan sosialnya. Oleh karena itu kesegaran jasmani adalah aspek yang tidak boleh dilupakan dalam tumbuh kembang anak. Selain itu, pembelajaran pendidikan jasmani juga berperan penting dalam upaya peningkatan kesegaran jasmani siswa di sekolah, antara lain dapat meningkatkan kemampuan fungsi organ tubuh, sosial emosional, sportifitas,dan semangat berkompetisi. Upaya kebugaran jasmani adalah upaya kesehatan yang memanfaatkan aktivitas fisik untuk meningkatkan derajat kesehatan. Apabila seorang siswa memiliki kesegaran tubuh yang baik dapat dipastikan siswa tersebut dapat melakukan kegiatan sehari hari dengan baik (Khalili Moghaddam \& Lowe, 2019). Oleh karena itu, perlu adanya tindak lanjut agar siswa dapat lebih memperhatikan kesegaran jasmaninya agar menjadi manusia yang berkualitas. Manusia yang berkualitas adalah manusia yang dapat memanfaatkan potensi fisik dan non-fisiknya untuk melihat dan merespon lingkungan sosialnya (Saunders et al., 2016).

Namun, di era milenial ini sering kali siswa merasa bosan dan jenuh dengan pembelajaran pendidikan jasmani yang dilakukan oleh guru di sekolah, dikarenakan para siswa yang sudah dimanjakan oleh berbagai kemajuan teknologi dan informasi dalam berbagai hal. Kita ketahui bersama di era modern ini kebanyakan siswa tergolong anak-anak digital native. Anak-anak digital native adalah anak-anak yang hidup dalam dunia digital, sudah paham mengenai ICT (information and Communication Technology), serta telah terbiasa menggunakan alat-alat digital tanpa harus kita ajarkan (Fu \& Technology, 2013). Padahal TIK memberikan dua keuntungan, yang pertama sebagai pendorong komunitas pendidikan (termasuk guru) untuk lebih apresiatif dan proaktif dalam maksimalisasi potensi pendidikan. Kedua, memberikan kesempatan luas kepada peserta didik dalam memanfaatkan setiap potensi yang ada, yang dapat diperoleh dari sumber yang tak terbatas (Budiman, 2017). Oleh karena itu perlu adanya inovasi mengenai media pembelajaran yang lebih mudah dipahami dan menarik bagi siswa,salah satunya dengan model pembelajaran mobile learning. Mobile learning merupakan bagian dari pembelajaran elektronik atau lebih di kenal dengan e-learning (Learning, 2012). Terkait dengan jumlah pengguna perangkat bergerak yang banyak di Indonesia, mobile learning dapat dijadikan sebagai salah satu sarana alternatif untuk pemecahan masalah tersebut. Pada era milenial ini kebanyakan siswa lebih disibukan dengan teknologi dan smarthphone yang memudahkan dalam segala hal. Sehingga, dengan adanya Mobile learning memungkinkan siswa untuk lebih mudah dan praktis mengakses materi-materi pembelajaran pendidikan jasmani (Adi \& Fathoni, 2020).

Mobile learning merupakan model pembelajaran yang memanfaatkan teknologi informasi dan komunikasi. Pada konsep pembelajaran tersebut mobile learning membawa manfaat ketersediaan materi ajar yang dapat di akses setiap saat dan visualisasi materi yang menarik. Istilah M-Learning atau Mobile Learning merujuk pada penggunaan perangkat genggam seperti ponsel, laptop dan perangkat teknologi informasi yang akan banyak digunakan dalam belajar mengajar, dalam hal ini kita fokuskan pada perangkat handphone (telepon genggam)(Fathoni, 2018). Tujuan dari pengembangan mobile learning sendiri adalah proses belajar sepanjang waktu (long life learning), siswa dapat lebih aktif dalam proses pembelajaran, menghemat waktu karena apabila diterapkan dalam proses belajar maka siswa tidak perlu menulis banyak tugasnya yang akan dikumpulkan kembali ke gurunya, cukup tugas tersebut dikirim melalui aplikasi pada mobile phone yang secara tidak langsung akan meningkatkan kualitas proses belajar itu sendiri (Abachi \& Muhammad, 2014).

Dari permasalahn diatas, maka pengembangan media pembelajaran berbasis mobile learning dalam aktifitas kesegaran jasmani sangat diperlukan agar siswa-siswi dapat memahami bagaimana penilaian dan kompetensi yang harus dicapai dalam kesegaran jasmani serta dapat mengakses materi-materi tersebut dengan praktis dan menyenangkan. Hal itu diperkuat dengan penelitian awal atau need assessment yang 
telah dilakukan peneliti pada siwa kelas X Perhotelan 3 SMKN 1 Batu. Adapun hasil dari need assessment atau penelitian awal yang peneliti lakukan di kelas X Perhotelan 3 SMKN 1 Batu diperoleh data $>75 \%$ siswa sangat memerlukan aplikasi berbasis mobile untuk menunjang hasil belajarnya, dan juga $>80 \%$ siswa sangat memerlukan aplikasi pembelajaran kebugaran jasmani berbasis mobile learning untuk memudahkn aktifitas belajarnya, serta $85 \%$ siswa tidak pernah mendapatkan materi pembelajaran berbasis mobile. Pemakaian media pembelajaran dalam proses belajar mengajar dapat membangkitkan keinginan dan minat yang baru, membangkitkan motivasi dan rangsangan kegiatan belajar, dan bahkan membawa pada tahap orientasi psikologis terhadap peserta didik (Kumar \& Nanda, 2018). Selain itu guru mata pelajaran pendidikan jasmani juga dapat dengan mudah mengakses materi-materi mengenai materi kebugaran jasmani dan kemampuankemampuan siswa yang harus dicapai pada tes kesegaran jasmani menurut (TKJI). Berdasarkan penjelasan yang tertera dalam latar belakang diatas telah disimpulkan bahwa penelitian ini akan mengkaji tentang : "Pengembangan media pembelajaran berbasis mobile learning untuk aktifitas kesegaran jasmani siswa kelas X Perhotelan 3 SMK N 1 BATU"

Tujuan penelitian dan pengembangan ini adalah mengembangkan media pembelajaran kebugaran jasmani berbasis Mobile Learning untuk membantu dan mempermudah siswa SMKN 1 Batu untuk mempelajari materi mengenai kebugaran jasmani.

\section{METODE}

Metode penelitian ini menggunakan prosedural pengembangan dari Darmawan (2014:60). Subjek yang digunakan dalam penelitian ini adalah siswa kelas X Perhotelan 3 SMKN 1 Batu dengan menggunakan Instrumen pengumpulan data berupa kuisioner atau angket. Menggunakan teknik analisis data kuantitaif dan kualitatif yang diperoleh dari pengolahan metode analisis kualitatif yang menggunakan triangulasi sedangkan analisis kauntitatif menggunakan deskriptif persentase. Langkah-langkah penelitian dan pengembangan pembelajaran multimedia adalah berikut.: (1) Analisis kebutuhan pembelajaran dan Analisis kurikulum, (2) identifikasi program meliputi: Judul, Tujuan, Materi, Sasaran, (3) membuat flow chart sesuai dengan model yang ditentukan, (4) membuat story board uraian dan flowchart diperinci setiap frame dan slide, (5) mengumpulkan bahan grafis, audio dan video, (6) Pemograman menggabungkan seluruh bahan, grafis, audio dan video, (7) finishing uji coba program (Ingleby, 2012).

Instrumen yang digunakan dalam penelitian pengembangan ini adalah kuesioner atau angket. Angket digunakan untuk mengumpulkan data kuantitatif dari hasil analisis kebutuhan, validasi ahli media pembelajaran, validasi ahli kebugaran jasmani dan uji coba produk pengembangan media pembelajaran kebugaran jasmani berbasis mobile learning.

Teknik analisis yang digunakan dalam penelitian dan pengembangan ini adalah teknik analisis kualitatif dan kuantitatif. Analisis kualitatif digunakan untuk mengolah data berupa kalimat yang berisi saran dari ahli media pembelajaran dan ahli kebugaran jasmani. Analisis kuantitatif digunakan untuk mengolah data yang diperoleh dari hasil penyebaran angket analisis kebutuhan, validasi ahli media pembelajaran, validasi ahli kebugaran jasmani, dan uji coba produk.

Untuk menentukan ketercapaian dalam penelitian dan pengembangan ini maka digunakan ketentuan nilai perhitungan presentase (\%) selanjutnya dikonversikan ke dalam bentuk kualitatif

Tabel 1 Konversi Hasil Perhitungan Presentase (Suharsimi;, 2013)

\begin{tabular}{cccc}
\hline No & Skala Presentase & Kategori Nilai & Predikat Hasil Evaluasi \\
\hline 1 & $81-100$ & A & Amat Baik \\
2 & $61-80$ & B & Baik \\
3 & $41-60$ & C & Cukup \\
4 & $21-40$ & D & Kurang baik \\
5 & $0-20$ & E & Kurang Sekali \\
\hline
\end{tabular}

HASIL

Hasil pengembangan akan disajikan data yang diperoleh dari analisis kebutuhan, evaluasi ahli media pembelajaran, evaluasi ahli kebugaran jasmani, dan hasil uji coba produk

\section{Analisis kebutuhan}


Berdasarkan hasil evaluasi analisis kebutuhan yang didapat diperoleh persentase sebagai berikut (1) 100\% siswa memerlukan model pembelajaran berbasis mobile (2) terdapat $65 \%$ siswa yang tidak pernah menjalankan aplikasi mobile sama sekali, (3) 100\% siswa memerlukan media pembelajaran untuk kebugaran jasmani, (4) $70 \%$ siswa memilih aplikasi pembelajaran sebagai media pembelajaranya(5) dan $100 \%$ siswa menyatakan bahwa sangat membutuhkan media mobile learning untuk mendukung pemahaman terhadap materi kebugaran jasmani.

\section{Ahli Media Pembelajaran}

Berdasarkan hasil validasi ahli media diperoleh hasil $96 \%$ yaitu masuk dalam kategori amat baik, dari hasil tersebut maka produk penelitian dan pengembangan media pembelajaran kebugaran jasmani berbasis mobile learning pada siswa SMKN 1 Batu dapat dilanjutkan pada tahap selanjutnya yaitu uji coba produk.

\section{Ahli Pembelajaran Kebugaran Jasmani}

Berdasarkan hasil evaluasi ahli pembelajaran Kebugaran Jasmani diperoleh persentase sebesar $100 \%$, sehingga pengembangan media pembelajaran kebugaran jasmani berbasis mobile learning pada siswa SMKN 1 Batu ini dapat digunakan sebagai media pembelajaran.

Hasil analisis kebutuhan di atas maka peneliti melakukan tanya jawab kepada pembina dan kepada siswa kelas X Perhotelan 3 SMKN 1 Batu bahwa belum ada media pembelajaran berbasis mobile learning. Selain itu siswa juga mengalami kesulitan dikarenakan minimnya refrensi untuk mendapatkan materi mengenai kebugaran jasmani.

\section{Uji Coba Produk}

Berdasarkan hasil uji coba produk yang telah dilakukan kepada siswa kelas X Perhotelan 3 SMKN 1 Batu menunjukan bahwa perolehan persentase $90 \%$. Jadi hasil tersebut menunjukan bahwa produk yang dikembangkan oleh peneliti masuk kategori amat baik, sehingga produk dinyatakan layak digunakan pada pengembangan media pembelajaran kebugaran jasmani berbasis mobile learning pada siswa kelas $X$ Perhotelan 3 SMKN 1 Batu.

\section{PEMBAHASAN}

Siswa SMKN 1 Batu terihat masih memiliki kekurangan dalam mengumpulkan bahan materi dan refrensi mengenai materi kebugaran jasmani. Hal tersebut dapat diketahui saat penulis melakukan observasi langsung dan bertanya jawab tentang materi yang didapatkan berasal dari mana dan media apa yang digunakan untuk memberikan materi kepada para pemain serta anggota yang baru untuk bergabung. Heinich (1993) mengungkapkan bahwa media merupakan alat saluran komunikasi

Media pembelajaran adalah Batasan medium sebagai perantara yang mengantar informasi antara sumber dan penerima (Ferguson, 2012). Sedangkan menurut Falachudin (2014:108) menyatakan bahwa media pembelajaran adalah segala sesuatu yang dapat menyalurkan informasi dari sumber informasi kepada penerima informasi (Géron, 2017). Pada dasarnya proses belajar adlah suatu proses interaksi yang terjalin melalui komunikasi anatara guru dan murid. Media pembelajaran atau materi pembelajaran (instructional materials) secara garis besar terdiri dari pengetahuan, keterampilan, dan sikap yang harus dipelajari mahasiswa dalam rangka mencapai standar kompetensi yang telah ditentukan (Gikas \& Grant, 2013). Dari beberapa pendapat diatas dapat disimpulkan bahwa media pembelelajaran adalah alat atau sarana penyamapaian informasi dari guru ke murid yang menjadi komponen penting dalam proses belajar mengajar, salah satunya adalah berbasis E-learning.

E-learning merupakan aplikasi internet yang dapat menghubungkan antara pendidik dan peserta didik dalam sebuah ruang belajar online. E-learning tercipta untuk mengatasi keterbatasan antara pendidik dan peserta didik, terutama dalam hal waktu, ruang, kondisi, dan keadaan. Melalui e-learning maka pendidik dan murid tidak harus berada dalam satu dimensi ruang dan waktu. Proses belajar dapat berjalan kapan saja dan dengan dimana saja (Rice \& Mckendree, 2013).

Berbagai manfaat e-learning baik bagi peserta didik, maupun pengajar membuat peneliti tertarik untuk mengembangkan media pembelajaran elektroinik berbasis mobile learning untuk aktifitas kesegaran jasmani SMK N 1 Batu. Tujuan dari diambilnya penelitian ini adalah agar dapat memudahkan guru dan siswa dalam proses pembelajaran, seperti yang dikutip dari salah satu sumber Pembelajaran online dan e-learning memungkinkan guru terpisah secara geografis dari siswa mereka, dan siswa dapat belajar dengan siswa lain 
di ruangan kelas seluruh dunia (Taleb, Ahmadi, \& Musavi, 2015). Jadi dengan adanya pengembangan aplikasi berbasis mobile learning diharapkan dapat menghilangkan ketergantungan siswa terhadap guru dan juga dapat memberikan kemudahan bagi guru dalam penyampaian informasi.

Berdasarkan pengumpulan data dari penelitian dan pengembangan ini akan disajikan data analisis kebutuhan, evaluasi ahli media pembelajaran, evaluasi ahli kebugaran jasmani, dan uji coba produk. Hasil penelitian dan pengembangan akan disajikan pada paparan berikut:

\section{Analisis kebutuhan}

Berdasarkan hasil penyebaran angket kuisioner untuk menganalisis kebutuhan diberikan terhadap 20 siswa kelas X Perhotelan 3 smkn 1 batu. Evaluasi analisis kebutuhan yang didapat diperoleh persentase sebagai berikut (1) $100 \%$ siswa memerlukan model pembelajaran berbasis mobile (2) terdapat $65 \%$ siswa yang tidak pernah menjalankan aplikasi mobile sama sekali, (3) 100\% siswa memerlukan media pembelajaran untuk kebugaran jasmani, (4) 70\% siswa memilih aplikasi pembelajaran sebagai media pembelajaranya(5) dan $100 \%$ siswa menyatakan bahwa sangat membutuhkan media mobile learning untuk mendukung pemahaman terhadap materi kebugaran jasmani.

\section{Evaluasi Ahli Media Pembelajaran}

Berdasarkan hasil validasi ahli media diperoleh hasil 96\%, dari hasil tersebut maka produk penelitian dan pengembangan media pembelajaran kebugaran jasmani berbasis mobile learning pada siswa SMKN 1 Batu dapat dilanjutkan pada tahap selanjutnya yaitu uji coba produk.

\section{Evaluasi Ahli Pembelajaran Kebugaran Jasmani}

Berdasarkan hasil evaluasi ahli pembelajaran Kebugaran Jasmani diperoleh persentase sebesar $100 \%$, sehingga pengembangan media pembelajaran kebugaran jasmani berbasis mobile learning pada siswa SMKN 1 Batu ini dapat digunakan sebagai media pembelajaran. Hasil analisis kebutuhan di atas maka peneliti melakukan tanya jawab kepada pembina dan kepada siswa kelas X Perhotelan 3 SMKN 1 Batu bahwa belum ada media pembelajaran berbasis mobile learning. Selain itu siswa juga mengalami kesulitan dikarenakan minimnya refrensi untuk mendapatkan materi mengenai kebugaran jasmani.

\section{Uji Coba Produk}

Berdasarkan data hasil uji coba produk media pembelajaran kebugaran jasmani berbasis mobile learning yang dilakukan pada siswa kela X Perhotealn 3 dengan jumlah sempel 36 siswa. Jumlah instrumen sejumlah 20 pertanyaan. Hasil uji coba produk yang telah dilakukan kepada parasiswa menunjukan bahwa perolehan persentase keseluruhan dari indikator kemenarikan, kebermanfaatan, kemudahan, kegunaan, kesesuaian, kerapain, dan kejelasan mendapatkan mendapatkan hasil persentase sebesar $83 \%$. Jadi hasil tersebut menunjukan bahwa produk yang dikembangkan oleh peneliti masuk kategori amat baik, sehingga produk dinyatakan layak digunakan pada pengembangan media pembelajaran kebugaran jasmani berbasis mobile learning pada siswa kelas X Perhotelan 3 SMKN 1 Batu.

Hasil penelitian yang menggunakan metode dari Darmawan (2011) mengembangkan media pembelajaran yang dikemas dalam bentuk aplikasi dengan menggunakan subjek siswa kelas X Perhotelan 3 SMKN 1 Batu menunjukan hasil yang sangat valid atau layak digunakan. Senada dengan penelitian dan pengembangan ini, produk pengembangan media kebugaran jasmani berbasis aplikasi android ini memperoleh hasil uji amat baik, sehingga produk ini dapat digunakan sebagai penunjang pembelajaran. Pengembangan media pembelajaran yang berupa aplikasi ini dianggap lebih menarik dan praktis daripada media lainnya, selain itu aplikasi yang dapat diakses di setiap smartphone siswa yang bertujuan untuk memberikan kemudahan dalam memberikan penjelasan tentang materi mengenai kebugaran jasmani. Sehingga dengan adanya teknologi pengembangan media pembelajaran menjadi trobosan yang sangat baik dan menarik untuk digunakan dari cara penggunaan dan biaya dibandingkan pembelajaran yang guru atau pelatih ajarkan.

\section{Uji coba efektifitas, efisiensi, dan daya tarik.}

Berdasarkan hasil uji efektifitas produk mengenai pengembangan media pembelajaran berbasis mobile learning untuk aktifitas kesegaran jasmani pada siswa SMKN 1 Batu terdapat hasil uji yang dilakukan sebanyak 2 kali. Pada pengerjaan uji yang pertama nilai rata-rata yang diperolah mahasiswa sebesar 77\% dengan kriteria baik, dan kemudian nilai rata-rata pda pengerjaan kedua diperoleh hasil persentase sebesar $83 \%$ dengan kriteria amat baik. 
Berdasarkan hasil uji efisiensi produk mengenai pengembangan media pembelajaran berbasis mobile learning untuk aktifitas kesegaran jasmani pada siswa SMKN 1 Batu terdapat hasil uji yang dilakukan sebanyak 2 kali. Pada pengerjaan uji yang pertama waktu rata-rata yang diperolah mahasiswa adalah 32 menit, dan kemudian nilai rata-rata pada pengerjaan kedua diperoleh hasil persentase adalah 29 menit. Berdasarkan hasil uji daya tarik produk mengenai pengembangan media pembelajaran berbasis mobile learning untuk aktifitas kesegaran jasmani pada siswa SMKN 1 Batu terdapat nilai hasil uji persentase sebesar $83 \%$ dengan kriteria sangat baik.

Dari data yang telah didapatkan dapat disimpulkan bahwa pengembangan media pembelajaran berbasis mobile learning untuk aktifitas kesegaran jasmani pada siswa SMKN 1 Batu siswa mengalami peningkatan terdiri dari aspek efektifitas, efisiensi, dan daya tarik terhadap produk kebugaran jasmani berbasis mobile learning.

\section{KESIMPULAN}

Penelitian dan pengembangan ini menghasilkan produk pengembangan media pembelajaran berbasis mobile learning untuk aktifitas kesegaran jasmani siswa SMKN 1 Batu. Pengembangan media pembelajaran tersebut dinilai dengan uji para ahli dan uji coba produk kepada seluruh siswa keals X Perhotelan 3 SMKN 1 Batu. Adapun hasil dari penelitian menunjukan nilai yang maksimal atau indeks Amat Baik, sehingga dapat disimpulkan pengembangan media pembelajaran Kebugaran jasmani sangat valid untuk digunakan untuk guru kelas, siswa, pelatih dan khalayak luas yang ingin mempelajari kebugaran jasmani. Harapanya dengan adanya penelitian ini dapat dijadikan referensi untuk penelitian-penelitian serupa di masa yang akan datang. Selain itu penulis juga berharap adanya pengembangan mengenai materi kesegaran jasmani dengan menggunakan subjek lain yang lebih besar agar dapat bermanfaat bagi khalayak luas.

\section{DAFTAR PUSTAKA}

Abachi, H. R., \& Muhammad, G. (2014). The impact of m-learning technology on students and educators. Computers in Human Behavior. https://doi.org/10.1016/j.chb.2013.06.018

Adi, S., \& Fathoni, A. F. (2019). Development of Learning Model Based on Blended Learning in Sports School. https://doi.org/10.2991/acpes-19.2019.2

Adi, S., \& Fathoni, A. F. (2020). The effectiveness and efficiency of blended learning at sport schools in Indonesia. International Journal of Innovation, Creativity and Change.

Budiman, H. (2017). Peran Teknologi Informasi Dan Komunikasi Dalam Pendidikan. Al-Tadzkiyyah: Jurnal Pendidikan Islam. https://doi.org/10.24042/atjpi.v8i1.2095

Fathoni, A. F. (2018). The Role of Blended Learning on Cognitive Step in Education of Sport Teaching by Adjusting the Learning Style of the Students. https://doi.org/10.2991/isphe-18.2018.49

Ferguson, R. (2012). The State of Learning Analytics in 2012: A Review and Future Challenges a review and future challenges. In Media. https://doi.org/10.1504/IJTEL.2012.051816

Fu, J. S., \& Technology, C. (2013). ICT in Education : A Critical Literature Review and Its Implications Jo Shan Fu. International Journal of Education and Development Using Information and Communication Technology.

Géron, A. (2017). Hands-on machine learning with Scikit-Learn and TensorFlow: concepts, tools, and techniques to build intelligent systems. In O'Reilly Media.

Gikas, J., \& Grant, M. M. (2013). Mobile computing devices in higher education: Student perspectives on learning with cellphones, smartphones \& social media. Internet and Higher Education. https://doi.org/10.1016/j.iheduc.2013.06.002

Ingleby, E. (2012). Research methods in education. Professional Development in Education. https://doi.org/10.1080/19415257.2011.643130

Khalili Moghaddam, G., \& Lowe, C. R. (2019). Physical activity. In SpringerBriefs in Applied Sciences and Technology. https://doi.org/10.1007/978-3-030-01557-2_2

Kumar, V., \& Nanda, P. (2018). Social Media in Higher Education. International Journal of Information and 
Communication Technology Education. https://doi.org/10.4018/ijicte.2019010107

Learning, W. (2012). The Future of Mobile Learning. Research Bulletin.

Rice, S., \& Mckendree, J. (2013). e-Learning. In Understanding Medical Education: Evidence, Theory and Practice: Second Edition. https://doi.org/10.1002/9781118472361.ch12

Saunders, D. H., Sanderson, M., Hayes, S., Kilrane, M., Greig, C. A., Brazzelli, M., \& Mead, G. E. (2016). Physical fitness training for stroke patients. Cochrane Database of Systematic Reviews. https://doi.org/10.1002/14651858.CD003316.pub6

Suharsimi;, A. (2013). Dasar-Dasar Evaluasi Pendidikan. Jakarta: Bumi Aksara.

Taleb, Z., Ahmadi, A., \& Musavi, M. (2015). The Effect of M-learning on Mathematics Learning. Procedia Social and Behavioral Sciences. https://doi.org/10.1016/j.sbspro.2015.01.092 